\title{
RICHARD G. MORGAN, 1903-1968
}

\author{
JAMES B. GRIFFIN
}

$\mathrm{R}$ ICHARD G. MORGAN, former Curator of Archaeology at the Ohio State Museum, died suddenly in Oaxaca City, Mexico, on November 15, 1968. He was born April 5, 1903, in Middletown, Ohio, and attended primary and secondary schools in that city. He received a B.A. degree from Ohio State University in 1926 and an M.A. in 1929, in Geology. He began graduate work in the Department of Anthropology at the University of Chicago in October, 1929, and continued his formal course work until 1932. In the M.A. thesis Morgan did what could be done at that time on identifying the sources of lithic materials used by the Indian groups in Ohio.

My first assocation with Morgan was in the fall of 1929 when he began his graduate work in anthropology at the University of Chicago. He had completed his formal work there except for a thesis which was to be on Ohio Hopewell. Morgan excavated in Fulton County, Illinois, with the University of Chicago in the summers of 1930 and 1931, along with Joe Brew, Fred Eggan, Thorne Deuel, George Neumann, Alden Stevens, Harold Driver, Dorothy Cross, David De Jarnette, Robert R. Jones, and other assistants. He made substantial contributions to the success of Fulton County excavations and to the analysis and description of the materials that appeared as Rediscovering Illinois in 1937.

In 1932, Morgan, Ritchie, and I were hired by the Pennsylvania Historical Commission under Donald A. Cadzow to do archaeological work. Ritchie was to work the West Branch of the Susquehanna in the Lock Haven area, I was to work the Susquehanna from Sunbury to the north, and Morgan was to work in the southwestern part of the state centered in Somerset. Morgan and I arrived in Harrisburg on the Friday afternoon before a Monday Memorial Day. We missed Cadzow who had left for his home in New York State and had to spend the long weekend in "Blue Law" Harrisburg. Cadzow arrived late Monday evening, and so did Ritchie. Tuesday morning we were shown the cars and equipment we were to have during the summer, but that leader of conservation forces, Gifford Pinchot, governor of the state, had vetoed the appropriation, and Morgan, Ritchie, and I were out of luck for the summer. This participation in adversity served as a cement for our future association.

Morgan had finished most of his formal course work by June, 1933, and spent most of that "Fair" summer in Chicago, helping relatives and friends see the fair, organizing a thesis topic, and working in the archaeological lab. He spent 1933-34 studying for exams, took a seminar or two, and had part-time work in the department laboratories. As a part of the Kincaid program of the University of Chicago, Morgan and Florence Hawley were paid by Fain White King to study the archaeological and dendrochronological material from that wellsalted site, the Ancient Buried City at Wickliffe, Kentucky, during the summer of 1934. Neither of them particularly enjoyed that experience.

Efforts were made in the academic year of 1934-35 to enable Dick to do field work in Michigan in the summer of 1935 and to begin a study of lithic material in the Museum of Anthropology, but neither of these materialized. Morgan passed his Ph.D qualifying exams in June, 1935.

Following a seige of illness, Morgan worked with me part of the summer of 1935 studying collections of W. K. Moorehead and A. R. Kelly at the University of Illinois, and then at Cornell College, Iowa, where we studied the collections gathered by Charles R. Keyes. The work in Urbana resulted in "Contributions to the Archaeology of the Illinois River Valley" in the Transactions of the American Philosophical Society, which was eventually published with a date of 1941 on it. Morgan and I essentially completed this report in the spring of 1938 , but the University of Illinois did not have money to publish it. Through the efforts of Fay-Cooper Cole and A. V. Kidder, it was finally accepted for publication.

On May 1, 1936, Morgan became Acting Curator of Archaeology at the Ohio State Museum and was named Curator in 1938. He had turned down earlier job offers for Federal Relief program excavations in the Southeast with the hope he would be able to develop a thesis. $\mathrm{He}$ felt that at the Ohio State Museum he would be able to put together an interpretation of Ohio 


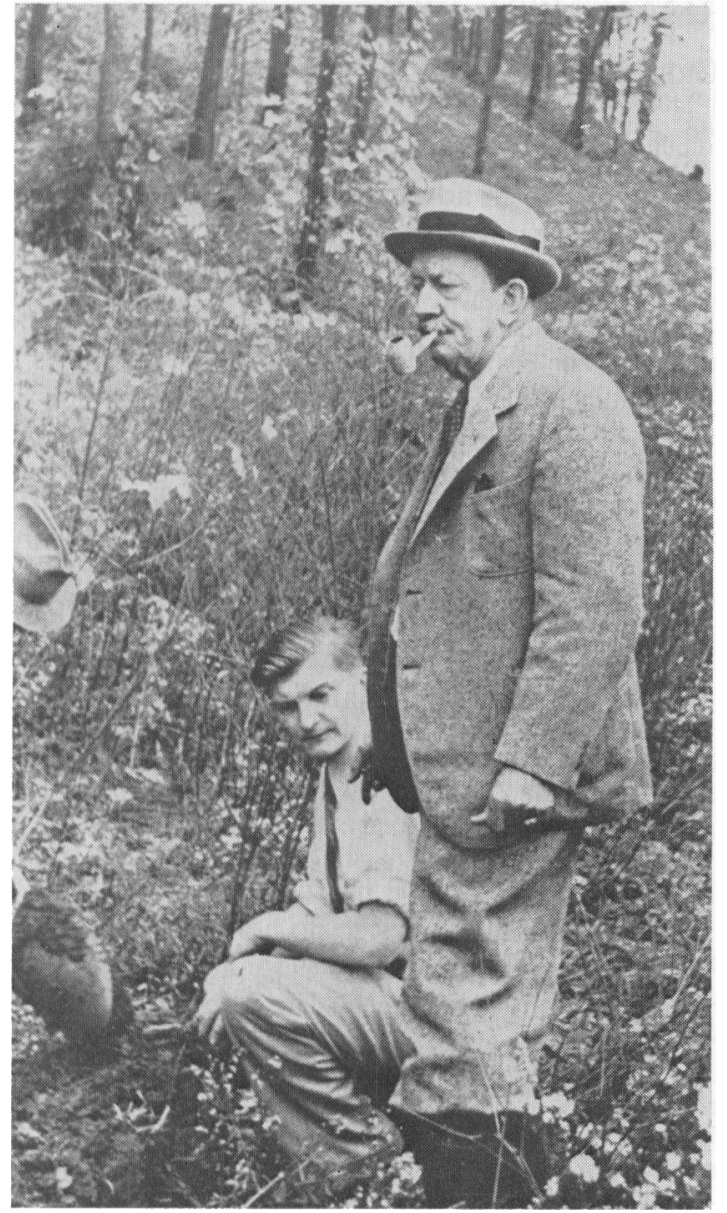

Richard G. Morgan

Hopewell that would identify regional differences and provide recognition of temporal changes. He replaced E. F. Greenman who returned to Michigan to direct the program in the Great Lakes Division of the Museum of Anthropology.

The photograph accompanying this article was taken in early October, 1936, along the east wall of Fort Ancient in Warren County, Ohio. W. K. Moorehead, the first Curator of Archaeology at the Ohio State Museum, is on the right; $\mathrm{H}$. C. Shetrone, the third Curator and at that time the second Director of the Museum, is on the left; and Morgan, who was the fifth Curator, is the third individual. Eli Lilly and Glenn Black had brought Moorehead from Indianapolis while I drove down to Columbus, and Morgan, Shetrone, and I went to Fort Ancient together. On the way over I expounded on my reasons for the Adena-Hopewell-Fort
Ancient sequence. Morgan's typical laconic comment was, "It will make interesting reading 15 years from now."

In the spring of 1937 the Lithic Laboratory at the Ohio State Museum was established; this was about the time that George Neumann began his studies of the prehistoric populations of Fort Ancient and related groups at the University of Michigan. H. Holmes Ellis, from the University of Michigan, was appointed to the Lithic Laboratory early in 1937 and was made Assistant Curator of Archaeology of the Ohio State Museum in 1939. Shetrone was primarily interested in flint-working techniques, so Ellis spent quite a bit of time on this phase of the work. Morgan was more interested in identifying the quarry sources, but he did participate in flint knapping, and he did produce a fluted point which Shetrone called "Morgan's Accident."

In the summer of 1937 Morgan, assisted by Ellis, excavated at the Fairport Harbor site and the report on this was issued in 1943. In the summer of 1938, Morgan and Robert Goslin excavated the Florence Mound, which was an Adena structure, in Pickaway County. In late August and September of 1939, Morgan and Ellis excavated for a few weeks at Fort Ancient in the Hopewellian village site in the area east of the fort wall and north of the road. They also dug in the southern part of the enclosure and found Hopewell and Fort Ancient material in the latter area. This was followed in 1940 by more extensive excavation aided by a group of Ohio State University students. During this time even more conclusive evidence was obtained that Fort Ancient was built by Hopewell culture people, for there was considerable evidence of occupation of Hopewell within and outside the so-called fort, and of only Hopewell material within the walls.

In 1941, Morgan and Ellis were again aided by students from Ohio State University in their excavations of the Dunlap mound just north of Chillicothe. Unfortunatelv, reports on the two mounds have not appeared, but some of the information on them was furnished by Morgan to W. S. Webb and was included in Webb's listing of Adena mound and artifact traits. Morgan furnished Webb with a considerable amount of information on Ohio archaeology.

With the war it was not possible to do much field work, and a considerable amount of time wns spent on exhibits and cleaning and curating 
the Augean stable-like Museum collections and storage. Morgan also devoted a considerable amount of time to exhibits in the Ohio State Museum, in the small Museum at Fort Ancient, and on the preparation of pamphlets on some of the state parks.

During the war, he was taken by the draft to Fort Benjamin Harrison, Indiana, where it was recognized that he did indeed have the physical disability that his doctor in Columbus testified he had and which limited his physical activity. Another desk job essentially completed during the war years was the Bibliography of Ohio Archaeology, which was the result of collaboration with James H. Rodabaugh, editor of the Ohio State Archaeological and Historical Society publications.

In 1947 Morgan married Mrs. Anna Rubio whom he had known when he was a graduate student at the University of Chicago. He is survived by his wife, her children by an earlier marriage, a brother, and three sisters.

Morgan left his position as Curator of Archaeology at the Ohio State Museum in 1947, but he did not give up his interest in archaeology or in anthropology. For a time he and his wife continued to live in the Columbus area, but they then moved to Chicago where he was employed with an insurance firm until the mid-1960's. He served as Honorary Curator of a Museum of African-American History in Chicago.

Dick and his wife went to Mexico in the late summer of 1968. After spending some time in the Valley of Mexico they went to Oaxaca, which he thoroughly enjoyed. I had an enthusiastic letter from him written November 1. It was a great pleasure to him to see some of the famous Mesoamerican sites for the first time. They were ready to leave Oaxaca in the middle of November when he suddenly died. $\mathrm{He}$ is buried in the Pantheon Jardin in Oaxaca City.

Morgan's major contributions were to midwestern archaeology, especially Illinois and Ohio. He was a reserved individual, but to those with whom he had an association of mutual confidence and respect he was a warm and understanding friend. He had a delightful sense of humor which, being rarely expressed, was all the more entertaining. His judgment on archaeological matters was sound and almost always conservative. He was not easily misled by the fervor of the proponents of ideas, or convinced by the weight of a book. His review of The Adena People is typical of his approach to the archaeological literature. His chapter in Archaeology of Eastern United States was a very fine one, presenting the views of the times on the prehistory of Ohio. From some points of view, it is still the best summary of Ohio archaeology.

\section{A Bibliography of Richard C. Morgan}

\section{3}

Archaeology of the Chicago Area. Transactions of the Illinois State Academy of Science, Vol. 25, pp. 91-2. Springfield.

\section{6}

An Interesting Burial at Fort Ancient. Museum Echoes, Vol. 10, p. 19. Columbus.

\section{7}

Ohio's Prehistoric Engineers. Ohio State Engineer, Vol. 20, pp. 2-5. Columbus.

An Indian "Doll" or Figurine. Museum Echoes, Vol. 10, p. 19. Columbus.

Archaeological Field Work (1937). Museum Echoes, Vol. 10, p. 43. Columbus.

1939

Warren King Moorehead. The Ohio State Archaeological and Historical Quarterly, Vol. 48, pp. 83-4. Columbus.

1941

A Hopewell Sculptured Head. The Ohio State Archaeological and Historical Quarterly, Vol. 50, pp. 384-7. Columbus.

(with Frank C. Baker, James B. Griffin, George K. Neumann, and Jay L. B. Taylor) Contributions to the Archaeology of the Illinois River Valley. Transactions of the American Philosophical Society, n.s., Vol. 32, Pt. 1, pp. 1-208. Philadelphia.

\section{2}

Ohio's Prehistoric Peoples. Museum Echoes, Vol. 15, pp. 39-40, 47-8. Part 2 under title: Our Prehistoric Indian Tribes. Columbus.

$$
1943
$$

(with H. Holmes Ellis) The Fairport Harbor Village Site, The Ohio State Archaeological and Historical Quarterly, Vol. 52, pp. 3-64. Columbus.

Sleuthing with the Archaeologist. Museum Echoes, Vol. 16, pp.51-2. Columbus.

\section{6}

Fort Ancient. The Ohio State Archaeological and Historical Society, Columbus.

Preserving Our Unwritten Records: A Comment on Archaeological Investigation. Museum Echoes, Vol. 19, pp. 75-7. Columbus.

Review of "The Adena People," by W. S. Webb and Charles E. Snow. American Antiquity, Vol. 12, No. 1, pp. 54-8. Menasha. 
1947

(with James H. Rodabaugh) Bibliography of Ohio Archaeology. Ohio State Archaeological and Historical So ciety, Vol. 189, p. 23. Columbus.

A Decorated Tobacco Pipe from the Madisonville Village Site. Museum Echoes, Vol. 20, p. 40. Columbus.

An Engraved Tomahawk Pipe. Museum Echoes, Vol. 20, pp. 15-16. Columbus.
1952

Outline of Cultures in the Ohio Region. In Archaeology of Eastern United States, edited by James B. Griffin, pp. 83-98. University of Chicago Press, Chicago.

UNIVERSITY OF MichigaN

Ann Arbor, Michigan

April, 1969 